\title{
TRÊS POEMAS PARA UM ENSAIO: TRADUÇÃO E CRÍTICA AFRODIASPÓRICA
}

RESUMO: Diante do ainda intenso cenário de discussões sobre a representação literária - e no limite, cultural -, este trabalho pretende discutir a crítica afrodiaspórico partindo de três poemas cuja autoria é a relevância do corpus. Em travessia, do campo da tradução literária e cultural partirá o caminho relevado para fazer ponte nesta discussão (tradução) crítica. Sendo o nosso corpus composto por três poemas de autoria afrodiaspórica como recorte, dos poemas escolhidos. Por outro lado, a minha formação como tradutor se deu - também - através dos discursos críticos da negritude, estudos culturais, filosofia e tradução cultural. Por isso, quis emergir do corpus poemas vindos de três línguas coloniais mais presentes no imaginário (em múltiplos sentidos). Assim, temos três poemas: um poema de língua hispânica, francesa e portuguesa. Por tal e por um motivo ou outro, temos os poemas em língua francesa e espanhola que serão traduzidos por mim. E, finalmente, um poema de língua portuguesa escrito fora do Brasil. Desejando com isso, dizer que afrodiaspórico não é uma circunscrição numa região geográfica ainda que não exista - afrodiaspórico - fora de alguma geografia. Em outras palavras, irei apresentar uma crítica à representação a partir e através dos estudos tradutórios e em seu processo criativo. É preciso dizer ainda que não há neste ensaio um desejo finalista visto que este (ensaio) mais bordeja o exercício filosófico para melhor entender relações. Tal como, em certa medida, fazem os estudos culturais e a negritude tomados neste trabalho como exemplo e rota (ator). Sem esgotar o possível, estudando em processo e construindo sem um fim.

PALAVRAS-CHAVE: Tradução; Afrodiáspora; Poesia; Epistemologia;

\section{Ensaio a relação}

Se partirmos de uma perspectiva histórica da construção do conhecimento no ocidente, através da hereditariedade dos seus sistemas escritos, esbarramos em sua lógica própria que nos impossibilitaria qualquer tradução. Os sistemas não podem ser traduzidos.

\footnotetext{
* Doutorando em andamento em Literatura e Cultura pela Universidade Federal da Bahia (Ufba).
} 
Não é possível. Já que, de dentro desse esquema (estrutura) a relação se dá, apenas, na condição de uma parte excluída (a lógica da identidade qual decorre a do terceiro excluído ${ }^{1}$ ); ou ainda, a partir da mútua exclusão das partes (a lógica da não-contradição) - no nosso caso, signo versus significante, original versus tradução etc. - por isso, não há lugar nessas oposições para o acidente, o acontecimento. Pois,

[...] se introduzirmos a noção de acontecimento, não como um evento ou um conteúdo que se localize no tempo (ao modo de Santo Agostinho) e sim como uma experiência (originária) que inaugura um presente, torna-se viável uma distinção entre tempo e temporalidade donde temporalidade como articulação dos acontecimentos uns aos outros através do encaminhamento singular de uma experiência (SODRÉ, 2017, p. 186).

Sendo assim, ao tomarmos o ato (fato) tradutório como um acontecimento inaugural de um tempo próprio, pois que, desse acontecimento recorremos à sua temporalidade e não ao tempo Histórico. Esse, por sua vez, é aqui entendido como um encerramento dos possíveis, uma estrutura pré-concebida. Por outro lado, a temporalidade é inaugural por apontar um fato novo, completamente desligado de uma presença anterior mesmo que não esteja, completamente, desligada da História, e, assim, do texto que lhe deu atributo (adjetivo) de tradução. Entretanto, passa ao largo a possibilidade de serem os mesmos textos. Em outras palavras, não habitam a mesma temporalidade; essa última, não é própria à "História”. Pelo dito, é necessário, também, perceber que entre a temporalidade e a História não existe uma relação binária: paralelizam. De outro modo, são (para nós) expressões epistemológicas culturalmente distintas. Embora

[...] não consigamos trabalhar sem elas, as oposições binárias [são] reducionistas e demasiadamente simplificadoras - engolindo todas as distinções em sua estrutura binária e um tanto rígida. Além disso, conforme afirma Jacques Derrida, existem pouquíssimas oposições

\footnotetext{
${ }^{1} \mathrm{Na}$ lógica Aristotélica, em conjunto com o princípio da não-contradição, que fazem parte das "leis do pensamento", diz: que em qualquer proposição ou, essa é verdadeira ou sua negação é verdadeira. Disso, toda relação entre diferenças se dá por oposição. Ou seja, não há nada que possa integrar o “entre” dessas relações de oposição. Em nosso caso, duas línguas que se coloquem equidistantes para uma tradução. Saem daí grandes questões do pensamento ocidental.
} 
binárias neutras. O filósofo argumenta que, normalmente, um dos polos é dominante, aquele que inclui o outro dentro do seu campo de operações (HALL, 2016, p. 154).

Seguiremos, então, ao retomar os caminhos que fazem deste trabalho, a partir da tradutologia, uma tentativa de reescritura paralela - por tentar um passo não-binário - à História mesma, a do ocidente e a dos seus sistemas simbólicos em sentido extenso. Isso, em conjunto com uma diversidade epistemológica que se produz de forma não estritamente geográfica mesmo que localizada, pois, em seu local, numa localidade. Tal local, é justamente o que nos possibilita transitar através das fronteiras das línguas em suas performances estruturadas, centradas. Uma vez que, em sentido meta-ambíguo, o localé um ritmo de intermitências cujas fronteiras são colocadas para o trânsito (para a dança), pois, a “dança [...] vocaliza, performa, grafa, escreve” nos diz Leda Maria Martins (2007, p. 81). Portanto,

Essa localidade está mais em torno da temporalidade do que sobre a historicidade: uma forma de vida que é mais complexa que "comunidade", mais simbólica que "sociedade", mais conotativa que "país", menos patriótica que patrie, mais retórica que a razão de Estado, mais mitológica que a ideologia, menos homogênea que a hegemonia, menos centrada que o cidadão, mais coletiva que "o sujeito", mais psíquica do que a civilidade, mais hibrida na articulação de diferenças e identificações culturais do que pode ser representado em qualquer estruturação hierárquica ou binária [...] (BHABHA, 1998, p. 199).

Sendo, por esses motivos, "organizações” simbólicas - episteme - de mediação das diferenças e identidades ("culturais") articuladas de modo compósito, em outras palavras, por meios “mais híbridos”. Pois, como observa Stuart Hall

Tudo o que dizermos e significamos é modificado pela interação e pela troca com o outro. O significado surge através da "diferença" entre os participantes de qualquer diálogo. O "Outro", em suma, é essencial para o significado (HALL, p.155, 2016). 
E, de modo suplementar, nos aponta Édouard Glissant sobre essa articulação (Relação), quanto ao modo, em sua localização e abertura, assim,

[...] estou me referindo às sociedades compósitas, às sociedades de crioulização - a noção de identidade que se realiza em torno das tramas da Relação que compreende o outro como inferência (GLISSANT, 2005, p.76 grifo meu)

Disso, tecemos, nas tramas da Relação com esse "Outro", ele mesmo, essencial para o significado, mas, também, "querendo assinalar que existe um abismo entre o abstrato reconhecimento filosófico e a prática ético-política (real-concreta) de aceitação de outras possibilidades humanas, da alteridade, num espaço de convivência (SODRÉ, 1999). E, ao se localizar em um "espaço de convivência", ou melhor, em pertencê-lo simbolicamente é que itero a mim noutra temporalidade, inclusive pela memória. Por isso, neste ensaio, a localidade é - também, e sobretudo -

Um agir político grupal [que] lastreia o pacto simbólico implícito nas formas de organização comunitária dos descendentes de africanos. É uma política que não costuma aparecer nas lentes etnológicas e se faz visível na mobilização dos recursos para a consolidação das alianças internas ao grupo e nas táticas de aproximação com a sociedade global hegemônica (SODRÉ, 2017, p. 185).

Com isso, e de volta aos termos iniciais, a experiência tradutória não pode ser caracterizada senão por conflitos, se e quando mobilizada das hegemonias geográficas das nações cujas fronteiras ditam o acesso ao dentro e ao fora, ao nacional e ao estrangeiro, em nosso caso, e mais precisamente, ao "original" e a tradução.

Pois, como vimos mais acima, pela lógica de uma episteme (europeia) fundada em um princípio de identidade cuja relação entre A e B exclui a possibilidade $\mathrm{C}$, e, mesmo a relação entre A e B só se dê por mútua exclusão e exaustão (não-contradição), como é possível, a partir dessa lógica, pensar a tradução? Visto que, o processo tradutório se dá, em geral, a partir de ao menos dois "textos" - em sentidos diversos - cujo processo se desenrola com a inclusão de um terceiro termo [?]. Como é possível a inclusão de um terceiro termo numa lógica binária, tal e qual a que apresentei acima? A partir dessa lógica 
é impossível - a inclusão de um terceiro termo. Mas, acontece de súbito. E a tradução toma a sua própria existência, numa própria temporalidade. Seguiremos mais alguns caminhos.

O mediador, o tradutor (como sujeito e tudo o que isso implica), e, também, como o terceiro, é aquilo [quem] possibilita a expressão dos símbolos traduzidos de um idioma a outro. Não é à toa que o fundamento da lógica do terceiro-excluído tenha esse nome, está no próprio nome da lógica a sua função: o terceiro está excluído. Porque, é a isso que essa lógica serve. Ela estabelece, dessa forma, os princípios de uma ciência que pretende excluir a subjetividade (o sujeito) que não deve interferir. Mesmo sendo (o sujeito), o próprio signo/símbolo da relação entre dois textos ou mais, em sua intertextualidade. E mesmo dessa forma, não deve relevar a si mesmo como sujeito relacional, exatamente,

Ali, [onde] a palavra poética, cantada e vocalizada, ressoa como efeito de uma linguagem performática do corpo, inscrevendo o sujeito emissor, que a porta, e o receptor, a quem também circunscreve, em um determinado circuito de expressão, potência e poder (MARTINS, 1995, p. 80).

E por incrível que possa parecer, a lógica da exclusão quer neutralizar a parte inominável (a subjetividade) daquilo que dá acesso à relação, ou seja, a própria relação como linguagem, no corpo e em sua temporalidade primordial. De outro modo, a linguagem-própria de um acontecimento, de um sendo no mundo.

Penso, então, no corpo próprio daquele que traduz. Pois, no corpo, o local pode expressar-se como a totalidade das subjetividades através das quais mediamos, traduzimos. Assim, é possível que o enlevo de uma episteme local sobrescreva uma dada ideia de tradução, pois, a localidade é determinante no modo particular de pôr as diferenças em relação. Por isso, também, é importante saber quem traduziu e, quando possível, suas questões acerca da tradução. Ou, como suas ações (ideologias) agem nesses contextos tradutórios.

Ainda com isso, desejo realçar uma leitura quanto ao fato de um terceiro - que não pode está posto ou assumido, como discurso, nas ciências humanas de tradição ocidental - ser o que possibilita a mediação das linguagens, em outras linguagens em traduções. 
Como se infere, a "textura" organizativa não se adequa a uma concepção psicologista em que o símbolo é pensado como um guia para orientar a ação humana, pertencente ao plano do imaginário. Mas, a narrativa comunitária [...] pode articular por meio de muitas representações uma simbologia derivativa com estratos semânticos complexos, cuja decifração jamais os esgota, a exemplo das camadas descascadas de uma cebola, que redundam em zero.

[...] Sendo assim, torna-se evidente a sua relação com o número um (número que rompe a imobilidade dos pares e permite a multiplicação), mas ao mesmo tempo com o número três, que não é primeiro e sim primordial: a dinâmica de reunião do terceiro constitui um e dois. Segundo os matemáticos, os números progridem do um ao dois, do dois ao três e do três ao infinito.

É o número três, portanto, que abre a possibilidade do infinito diverso. Mas é também aquele que possibilita a linguagem, uma vez que cada som verbal aparece como um terceiro elemento, resultante da interação de dois elementos genitores - entidade transcendente e ser humano [...] (SODRÉ, 2017, p. 191, grifo nosso).

Antes é preciso explicitar que o filósofo, o baiano Muniz Sodré, ensaia - na citação acima - uma leitura relativa à potência de Exu como um princípio dinâmico das relações sígnica (simbólicas). Para, então, relevar como certas matrizes africanas na diáspora realiza, de modo diferente, a sua relação com o simbólico, com o símbolo. Pois, não se "adequam” a um psicologismo onde o símbolo épensado como um guia para orientar a ação bumana, pertencente ao plano do imaginário $[\mathrm{x}]$. No limite, isso quer dizer: uma outra epistemologia. Ali, nomeada como: Pensar Nagô. E ainda nos acresce Muniz Sodré (2017): "Um pensamento sútil” ou

[...] uma filosofia "de negociação" [...], sem entender "negócio" apenas pelo vezo moralista das trocas comandadas pelo capital e sim como também a troca simbólica do dar-receber-devolver, aberta ao encontro e à luta na diversidade. É precisamente o que queremos dizer com "pensar nagô" (SODRÉ, 2017, p. 24).

Ao que podemos apontar, por alargamento, à ideia de um pensamento arquipélico de Édouard Glissant, e até reunirmos outras epistemologias que se dão a ver através do seu local, em seus traços, cujas identidades compósitas estão sempre em exercício para uma resultante imprevisível dos seus processos de interações simbólicas (com o simbólico). Tudo dito, está, fundamentalmente, ligado aos sujeitos que "são" memórias pessoais de eventos comuns de uma localidade. Onde, "a questão do ser não se apresenta mais a partir 
da visão dessa solidão vantajosa à qual havia se reduzido o pensamento universal" (GLISSANT, 2005, p. 59). Mais adequadamente, um pensar afrodiaspórico em uma geografia derivante. Como algumas culturas das ilhas no atlântico, em um arquipélago no indico, no Nordeste do Brasil ou, mais intimamente, em Salvador na Bahia ou em sua baía de todos santos. E que a mim se parecem como estrelas brilhando em fundo negro, na noite do mundo. No tempo que a flagramos já perdido, e, ainda, nos corpos.

Expostas essas questões em torno das temporalidades locais e seus sujeitos, com as quais tentamos paralelizar questões mínimas para outra ordem epistemológica - em algumas especificidades da geografia afrodiaspórica - e, com isso, pensarmos a tradução como um acontecimento de linguagem simbólico, em nosso caso, a tradução verbal. Sem esquecer que essas, são as condições, também, do corpo daquele quem traduz e, portanto, da sua subjetividade particular e coletiva.

Por tudo isso, a tradução como acontecimento, seria mesmo pensar o impossível? Em paralelo a essa questão, o filósofo argelino Jacques Derrida, aponta que

Talvez se tenha produzido na história do conceito de estrutura algo que poderíamos denominar um "acontecimento" se esta palavra não trouxesse consigo uma carga de sentido que a exigência estrutural ou estruturalista - tem justamente como função reduzir ou suspeitar. Digamos, contudo, um "acontecimento" e usemos esta palavra entre aspas. Qual seria, portanto, esse acontecimento? Teria a forma de uma ruptura e de um redobramento (DERRIDA, 1971, p. 229).

Assim, se por ruptura tomarmos a imagem de uma "abertura brusca". E por redobramento, o debruçar-se do texto em direção a um outro texto, alcançamos, desde já, uma ideia tradutória. Pois, por tradução, nos diz Édouard Glissant:

A tradução é como uma arte da fuga, ou seja, tão sutilmente, realiza uma renúncia. Há renúncia quando o poema, transcrito em outra língua, deixou escapar uma grande parte do seu ritmo, suas estruturas secretas, suas assonâncias, essas coisas que são o acidente e a permanência da escrita. Devemos consentir neste exaurimento, e essa renúncia é a parte de si mesmo, que em toda poética se abandona à outra. A arte de traduzir nos ensina o pensamento da esquiva, prática do traço que, contra os pensamentos de sistema nos indica o incerto, 
o ameaçado, os quais convergem e nos afirmam. Sim, a tradução, a arte de aproximar e roçar, é uma constância do traço. (GLISSANT, 1990 , p. 48 , grifo meu $)^{2}$

Também por isso, uma ideia de "ruptura e redobramento" (DERRIDA, 1971) logo esposaria o "acidente e a permanência da escrita". Através da intertextualidade (HALL, 2005) dos corpora, das línguas e suas imagens, do tempo por suas temporalidades sob o nome de acontecimento (SODRÉ, 2017). Todos esses, reunidos sob um modus em tradução. Logo, mediados por uma epistemologia que possa escutar os signos que os símbolos permitem construir em Relação.

Portanto, o texto produto de uma tradução pode não recorrer à estrutura lógica ocidental, pois essa, nada renuncia em seu funcionamento ou em sua lógica da diferença. Aquela resultante imprevisível (a tradução), digamos assim, não decorre de. Não é comparável a. Não concorre a um tempo que derive algo. Uma vez que, a sua fonte se perde por ser ela mesma o tempo que inaugura (uma temporalidade). Distante da ideia fixada no transcorrer linear da história-episteme platônica que montou o esquema binário, onde a tradução fora posta e, desde então, enclausurada. Ou mesmo, como cópia ou produto infiel do seu original, isso é

[...] uma primeira determinação do motivo platônico: distinguir a essência e a aparência, o inteligível e o sensível, a ideia e a imagem, o original e cópia, o modelo e o simulacro. Mas já vemos que estas expressões não são equivalentes (DELEUZE, 1974, p. 264).

Assim sendo, não vou recorrer à história da tradutologia que remontaria a quase dezoito séculos cuja visão reitera geralmente um caminho que aqui é um tanto dispensável. Pois, essa história "começa"

[...] com a recepção das palavras gregas no pensamento romano-latino. Hypokeimenon torna-se subjectum; bypostasis torna-se substantia; symbebekós torna-se accidens. Esta tradução dos nomes gregos para a

2 Tradução minha. Essa, e todas as outras citações de Édouard Glissant. Exceto, Glissant (2005). 
língua latina não é de modo algum um fato sem consequências em relação a eles, como hoje ainda é julgado. Por detrás da tradução, aparentemente literal e preservadora, esconde-se muito mais um transpor da experiência grega para um outro modo de pensar. $O$ Pensar romano assume as Palavras gregas, traduzidas sem a experienciação igualmente originária que corresponda ao que elas dizem, sem a experiencial palavra grega. Com este traduzir começa a carência de chão firme do pensamento ocidental. (HEIDEGGER, 2010, p. 52-53, grifo $\mathrm{meu})$

É de "chão" que a tradução precisa. E, é - justamente - o local, um chão com o qual pensamos o ato tradutório, a ação tradutora. De um corpo - ‘são' (plural do verbo) - no sentido de que esse corpo reúne, como pensamento, a dinâmica (potência de toda subjetividade) de uma localidade. Essa reunião é um sendo no mundo. Não um estar, como alguém soterrado pelo chão em que pisa. Por tudo dito, o campo da tradução, mais recentemente, tomou contornos diversos quando abordada sob proposta revisionista de sua lógica; e, re/ localizadora em sua interpretação teórica ou sob olhar de outras epistemologias. Por esses caminhos percorreremos, ainda.

\section{O diverso são caminhos}

Entre esses novos rumos, os Estudos Culturais - em sua multiplicidade de rotas interpretativas da realidade anistórica - nos permite aportar em (para) um espaço onde o possível é toda realidade humana e não somente uma parte escolhida, objeto de alguma ciência restritiva. Esse modo de fazer ciência consiste sobretudo numa formação discursiva (HALL, 2003). Ou seja,

A expansão do olhar sobre textos, autores, temas, situações e experiências, de certa forma até então exilados da reflexão crítica, dos meios e circuitos de veiculação e de reconhecimento, distende nossa cartografia literária e desafia as redes discursivas formadoras de juízo e de opinião (MARTINS, 2007, p. 57). 
Ainda, desejo relevar que não é somente o real 'concreto', objeto de alguma razão capaz de apreendê-la em definitivo, mas a própria relação a ser estabelecida, pois, os “estudos culturais tiveram uma grande diversidade de trajetórias" que nos mantém, a grosso modo, numa deriva interpretativa (HALL, 2003). Quero dizer com isso, sem a aspiração em aportar numa hermenêutica totalizante. Destarte, não nos interessa as repostas gerais quanto aquilo que é uma tradução (definitivamente) ou quais são suas bases essenciais. Nem por isso, objetivaremos "um pluralismo simplista" como diria Hall (2003), sobre os estudos culturais, o qual ratificamos aqui em nosso projeto tradutório como um modo ou o "limite metodológico" para essa “comunicação transcultural” (SODRÉ, 2017), ao pensar a tradução afrodiaspórica.

Em um contexto específico, os estudos da tradução vêm se ressemantizando em torno de uma geografia na qual a própria história não tem valor cumulativo, positivo. Não se conduz para um fim tal qual apontara a teoria (a estética) hegeliana ${ }^{3}$, como também observa Stuart Hall (2003) em Da diáspora. Esse espaço, essa geografia, pode ser reconhecida a partir dos seus territórios fronteiriços: linguísticos e culturais - praticamente em sua totalidade - desenhados arbitrariamente no processo colonial, decolonial. Falo diretamente das fronteiras geográficas demarcadas sobre o território físico. No entanto, reconhecer a existência desses lugares cujas fronteiras riscam ao mesmo tempo a história e os corpos não é adotar os princípios excludentes delas. Apenas nos serve como atestadores das realidades que não são as nossas. De outra forma, como Heidegger (2012) apontara, as fronteiras não podem demarcar um fim, mas, e tão somente, um novo começo.

Por conseguinte, desejo abrir o processo de relação que temos com o texto, me estabelecendo através da ação de tradutor, sem que as partes desejem excluir-se mutuamente para impor-se concretamente diante de uma realidade subsumida.

\footnotetext{
${ }^{3}$ Dessa estética, os processos criativos, arte e o belo, são um todo histórico e real. A arte tem um fim em si mesma. Sem finalidades morais ou pedagógicas. Ao mesmo tempo, manifesta o espirito de um povo em seu estágio na história. Esse sentido histórico cujo progresso é orientado pelo processo civilizatório europeu compõe praticamente toda medida e direção. Ou seja, aí se compõe o centro por onde todos os processos artísticos (epistemológicos) deve obter sua medida, obrigatoriamente.
} 
Admito desde já, que em meu processo tradutório não há o desejo exclusivo, mas relacional. Não tentarei tomar um idioma por outro. Ensinar o caminho da interpretação pura. Mas, acima de tudo, recuar para o lugar das relações por meio de culturas paralelizadas através do reconhecimento de línguas diferentes. Para então, irmos ao encontro das experiências pelos quais certos corpos (racializados), por meio de outro sistema linguístico-hegemônico, se relacionaram com a produção do texto escrito. Como quem ler cartas endereçadas a um ponto de encontro. E não a um local restrito, localizado. Um endereço previamente nomeado ou uma ciência formalmente estabelecida.

A ideia de tradução, portanto, pode também ser vista através dessa geografia que se estabelece a partir desses encontros. Como um caminho equivocado que inaugura uma trilha, existente desde já, inconcebível até que se tente. Assim sendo, a própria relação daquele que pisa com o chão pisado. Não é o chão quem me levará adiante, nem o passo apressado ou desconfiado, a um outro lugar possível, existente, mas não conhecido. É: ao se relacionar com o incerto tomando-o como um dado do real; do imprevisível, já admitido, e que mesmo assim não deslinda em paralisia, mas, nos conduz ao diverso (GLISSANT, 2005). Nos conduz, mais precisamente, a um dos seus nomes, à Tradução.

Esse lugar onde experimento essa possível tradução, citado mais acima, é justamente o espaço geográfico de uma localidade cuja própria relação espaço-tempo, geografiahistória tenha sido riscada pelo estabelecimento violento das suas fronteiras, na repartição do território colonial. Visto

[...] que a geografia é algo a se levar em conta na perspectiva de outros modos de pensar. E o que aqui apresentamos é a perspectiva de um modo afro de pensar tipificado no sistema nagô, que é de fato uma forma intensiva de existência (forma em que a passagem do biológico ao simbólico ou ao "espiritual" é quantitativamente significativa), com processos filosóficos próprios. "Afro" não designa certamente nenhuma fronteira geográfica e sim a especificidade de processos que assinalam tanto diferenças para com os modos europeus quanto possíveis analogias (SODRÉ, 2017, p. 15). 
De outro modo, o redobramento pode ser uma forma de intensidade, assim como, a ruptura é uma abertura, aqui, das hegemonias nacionais, do cânone ocidental e, por consequência, do conceito de tradução em sua intertextualidade.

\section{Em uma geografia incerta}

Entretanto, e acima de tudo, falamos aqui também de um lugar incontornável (GLISSANT, 1997). Um território incapaz de ser contornado que muitos chamam de geografia Afrodiaspórica. Ou seja, uma realidade que não pode ser domesticada por um pensamento utópico, no sentido de que aí se forme lugar ideal para o encontro reterritorializante. Esse espaço, é somente geográfico na medida dos corpos e dos seus trânsitos.

Mas, é também pode ser localizado: seja o Harlem ou Havana, São Luís e Luanda. É tanto, o detalhe e a totalidade que fala Glissant (1997). Sem que fronteiras coloniais possam cercá-los, circundá-los. Por isso, espaço incontornável. Perceptível na geografia ocidental à medida que as fronteiras aí estabelecidas nos servem como parâmetros da sua própria lógica e, por extensão, do espaço afrodiaspórico ultrapassado pela linguagem comum das gentes que sabem de si sem se conhecerem. Reconhecem-a-si si pelos modos de se porem em Relação. À maneira descrita por Édouard Glissant (1997, p. 16), por suas “poéticas difratadas desse Caos-mundo que compartilhamos [...] e das quais necessitará que aproximemos as invariantes".

Do mesmo modo, e sentindo-me nessa geografia, nesse espaço possível, [mas, não fixado num contorno cujas fronteiras são o lugar mesmo da relação com o outro, com a outra língua] coloco-me para uma tradução. Esse tipo de tradução não é o continuum uniforme resultante de um processo de semelhanças contrastantes que fazem funcionar, a partir de um sistema, um outro. Não reconhecemos o limiar em que interdição e ou permissão faça operar um conjunto de linguagens, no caso, a escrita, a reescrita entre línguas, em outras palavras, o processo tradutório.

De tal forma, se considerarmos as diversas recriações que se deram e continuam a se dar nas culturas Afrodiaspóricas, como lugar-comum da diversidade que relevamos nesse trabalho, “aportamos, nomeadamente, na diversidade” (GLISSANT, 1997, p. 23). 
Esse espaço, Afrodiaspórico, cuja forja coincide com a exploração comercial das gentes do continente africano, redimensionado no processo de descolonização ou decolonialidade (como preferir), coloca em evidência a formação persecutória de estados nações, com línguas e sistemas culturais nomeados e apresentados nos dias de hoje, fundamentalmente, pelas línguas-colônias (inglesa, francesa, espanhola e portuguesa).

Consequentemente, estabelecidas sob a lógica do logos em seu funcionamento usual que - dentre tantas maneiras - pode ser circunscrita de modo a exemplificar e contextualizar nosso trabalho, a partir de conceitos extensamente citados e analisados tais como: significado-significante, original-tradução, Nós versus Eles [A não-é B]. Conceitos limites na direção da interdição, da circunscrição de ideias, objetivo mais que aparente de um modus cultural europeu. Por outro lado, as culturas forjadas - digo dessa forma, pois fora a golpes violentos que a empresa colonial se deu - nesse contexto (afrodiaspórico) foram expostas a um sem número de traços identitários advindos do continente africano e mesmo europeu além dos que já habitavam esses lugares. Não é possível, assim, ao menos nesse momento do nosso tempo, estabelecermos um lugar dissecado que nos habilite ao reconhecimento da nossa própria formação cultural de modo acabado, concluído. Do mesmo jeito que ao modo atávico das hegemonias coloniais que buscam o próprio estabelecimento em explicações universais (GLISSANT, 1997).

Portanto, o reconhecimento dos nossos traços identitários pode, inclusive, ser relacionado a um outro lugar dessa geografia afrodiaspórica independentemente das suas línguas coloniais, apesar disso, essa não é a questão que propomos neste ensaio. E, nem caberia.

Mesmo assim, partimos da ideia de que existem limites geográficos quando há uma vontade em conduzir essas fronteiras para mais adiante. Quando dominar o todo é a expressão do desejo universal dessas culturas ocidentalizantes. Por isso, a questão da língua não emerge como paradigma derrisório do que chamamos por tradução. A língua, local fronteiriço de uma outra sociedade, é, nesse caso, um limite estabelecido para que o lugar possível dessa diáspora negra não se dê, portanto, suprimível no instante que tracejo o 
encontro dos corpos, do reencontro na dança, na música, na crença ou na maneira incontornável do nosso mundo não restrito à língua, nem circunscrita a uma geografia compartilhada sob o signo de nação. E, sobretudo, a partir de uma identidade epistemológica não escrita no tempo histórico ocidental. Visto que,

Com essa experiência temporal se constrói a atualidade e, consequentemente, a Modernidade, que se tem definido pelo predomínio cultural do tempo sobre o espaço. Também a escrita, que legitima o ser moderno, é outra experiência autorizada pelo tempo. O próprio "fim" da experiência tradicional anunciado por Walter Benjamin é, na realidade, o fim da autoridade da autópsia - o ver por si mesmo, garantido pelo espaço - em favor da escrita, garantida pelo tempo. (SODRÉ, 2017, p. 184 grifo meu)

Os caminhos que nos levam a esse outro, que nós somos, não perpassa a insondável opacidade da língua, mas, sim, o estar em trânsito por experiências tradutórias próprias aos corpos que submetidos às suas realidades compartilham o mundo na opacidade da cor, mesmo que através de um outro idioma. Por tudo isso, onde localizar o tradutor, digamos, pós-colonial? E, mais devidamente, ao meu caso, o tradutor de negro? Esse tradutor, mesmo que não seja subsumível a esses esquemas das ficções (ou fixações) das línguas, mas, nem por isso, as objetam. Em nosso caso, propriamente dito, a língua é um lugar cuja abertura (opaca) nos dar a ver o outro, o mais; pois, o texto escrito, é já uma autoridade que expõe algo, sendo, por isso, o lócus preferencial das culturas coloniais (em suas instituições) e é, acima de tudo, por esse motivo que nos centramos no texto verbal. Nesse texto, se fundou religiões, contratos, relações excludentes e nações; - todo ocidente?

O texto escrito, sagrado ou legal, no emaranhado das culturas, pela filosofia (ciências) ou com a literatura (as artes), se estabeleceu para comprimir outras realidades fora do próprio esquema escrito versus não-escrito. No entanto, seria possível, mesmo que através dessas línguas, estabelecermos outros lugares de partida além do texto escrito no percurso tradutório de textos escritos? Nesta disposição cultural, das questões afrodiaspóricas, como o tradutor se relaciona a um contexto cujas realidades se aproximam, mas as línguas os afastam? 
Postas essas questões, será necessário dispor de todos os elementos dessa geografia sem fronteiras numa relação de leitura e interpretação. Melhor, de reconhecimento de traços, trejeitos, expressões e narrativas em que corpos se assemelham num lançar-se em reinscrição de si, através de uma localidade, numa geografia cointensiva mesmo que distantes no mapa. Como pensa Édouard Glissant (2008), onde a ilha é mais que uma metáfora quando se abre ao mar, pois, suas "correntes" nos fizeram aportar a diversidade através de um rastro, como um traço sulcado em mapas jamais desenhados,

Contra as reviravoltas dessas velhas estradas já trilhadas, o rastro/resíduo é a manifestação fremente do sempre novo. Porque o que ele entreabre não é a terra virgem, a floresta virgem, essa paixão feroz dos descobridores. $\mathrm{Na}$ verdade, o rastro/resíduo não contribui para completar a totalidade, mas permite-nos conceber o indizível dessa totalidade (GLISSANT, 2005, p. 83).

Por isso, compomos um corpus em três línguas - francês, espanhol e português com três poemas escritos em cada uma dessas línguas. Desses poemas, irei traduzir dois (um espanhol e outro em francês) imaginando suas poéticas em tradução, em relação ao meu processo tradutor, apontando para outros caminhos que não perpassem o esquema de "poder" representacional em que opera o sistema linguístico ocidental na mediação das alteridades, para a interdição própria, da "diferença”. Fica, assim, a explícita

[...] conexão entre representação, diferença e poder. No entanto, é preciso sondar mais profundamente a natureza deste. Muitas vezes, pensamos no poder em termos de restrição ou coerção física direta, contudo, também falamos, por exemplo, do poder na representação; poder de marcar, atribuir e classificar; do poder simbólico; do poder da expulsão ritualizada. O poder, ao que parece, tem que ser entendido aqui não apenas em termos de exploração econômica e coerção física, mas também em termos simbólicos ou culturais mais amplos, incluindo o poder de representar alguém ou alguma coisa de certa maneira - dentro de um determinado "regime de representação". Ele inclui o exercício do poder simbólico [...] (HALL, 1997, p. 193). 
Diante o exposto, tentaremos escutar as críticas vindas dos poemas. Pelo que expõem das subjetividades escancaradamente críticas a esse esquema, ou regime representacional da raça negra, do homem negro, realçados por suas localidades mesmo que em línguas diversas. Mas, e sobretudo, "sublinhando o diverso leque de matizes e linhagens que traduzem a afrodescendência, caligrafada na e pela letra literária” (MARTINS, 2007, p. 5). É por isso, também, que o terceiro poema, em língua portuguesa, nos traduz uma subjetividade negra localizada no continente africano em língua colonial; Essa África, como observa Nietzsche (2009), é geográfica e não metafisica, corroborado por Muniz Sodré (2017). Portanto, esse poema de em língua portuguesa, mas, retecido no continente africano, obviamente, não necessitará de uma tradução interlingual digamos assim. Mas, a sua expressão significativa (em língua portuguesa) nos aponta um encontro marcado, a encruzilhada símbolo deste exame tradutório. Através, também, da minha própria língua se assim posso dizer, depois de tudo, ao me referir à língua de Portugal.

No mais, os autores dos poemas são Nicólas Guillen (Cuba), Agostinho Neto (Angola), René Philombé (Camarões); e foram, por motivo ou outro, escolhidos para encontrarem-se aqui sob uma análise tradutória em seus aspectos críticos às ideias de representação fixadas - de e por diversas maneiras - num corpo uno, cognominados no processo de tráfico e escravidão de pessoas cujos motivos indelevelmente claros objetivaram a raça negra, independentes de suas particularidades. Posto que, é necessário lembrar que,

[...] teoricamente, o argumento que nos permite desenvolver esta questão é a proposta [...] de que o significado nunca poderá ser fixado. Se isso pudesse ser feito por meio da representação, então não haveria qualquer mudança - e, por isso, nenhuma contraestratégia ou intervenção (HALL, 2007, p. 211).

Pois, "em última análise, entretanto, o significado começa a escorregar e deslizar. Começa a derrapar, ser arrancado ou redirecionado. Novos significados são enxertados nos antigos" (HALL, 2007, p. 211). Isso, também se entrevê no processo crítico de uma tradução afrodiaspórica quando percebemos, nesse processo, que as 
Palavras e imagens carregam conotações não totalmente controladas por ninguém, e esses significados marginais ou submersos vêm à tona e permitem que diferentes significados sejam construídos, coisas diversas mostradas e ditas (HALL, 2007, p. 212).

Mas que, no entanto, além do processo próprio ao tradutor em seu exercício de linguagem, auxiliado por corpus teórico não necessariamente ligados à tradutologia, espero não mais que o indeterminado subjacente a qualquer tradução bem como à opacidade autodeterminada em qualquer outro corpo,

No encontro das culturas do mundo, [onde] precisamos ter a força imaginária de conceber todas as culturas como agentes de unidade e diversidade libertadoras, ao mesmo tempo. É por isso que reclamo para todos o direito à opacidade (GLISSANT, 2005, p. 86).

Em nosso ensaio, poderíamos dizer, atalhando qualquer conceito, que "essa é a errância violenta do poema” (GLISSANT, 2005, p. 20), ou ainda, das poéticas em tradução que nos diz Sodré (2017) com um aforismo nagô.: "Exu matou um pássaro ontem com a pedra que atirou hoje", ou seja, numa temporalidade cuja subjetividade realçamos sob o aspecto critico de Tradução Afrodiaspórica. Tudo isso, me serve para inventar-me de um modo em que a língua não abisme as poéticas em tradução, num corpo próprio que agora ensaio, e, pelo qual contorno.

\section{A língua da poesia ou o corpo da tradução}

Percebemos, então, que a tradução de textos escritos exige mais que a relação entre-línguas, interlingual. Disso e como já expressei anteriormente, me estabeleço para a construção de um corpo-texto a ser determinado de modo genérico por tradução, em língua portuguesa do Brasil, de três poemas compostos por três poetas da raça negra em que os temas estejam circundando suas relações de corpo-língua. Para, e com isso, tentar perceber o processo tradutório de um texto de partida em direção a um texto alvo que se dá, de forma imprevisível, inaugurando, tal como um acontecimento, um tempo próprio. Propondome redigir em português o apagamento das línguas estrangeiras. Pois, 
Apaga-se conservando legível, destrói-se dando a ver a ideia mesma do signo. Enquanto de-limita a onto-teologia, a metafísica da presença e o logocentrismo, esta última escritura é também a primeira escritura (DERRIDA, 2000, p. 29).

Ou seja, a escritura desse novo texto - essa tradução, que é também a última escritura de um texto e por isso mesmo a primeira (do seu próprio tempo) - possa ir ao encontro de um conhecer parcial das realidades afrodiaspóricas em ambientes diversos e não circunscritos pelas fronteiras da língua. Para expor um ou outro corpo em suas experiências próprias, mas, compartilhadas.

Assim, traduzir seria um riscar (apagar) dando a ver a lógica própria do signo, de sua ideia. Escrevendo sem substituir. Empregando o novo que se diz em outra língua sem a ela recorrer (em profundidade), isso quer dizer: sem condicionar a tradução aos idiomas impostos.

No entanto, além do processo próprio relativo à palavra, o corpo da tradução empreende-se numa realidade extralinguística com aqueles que escreve, com a própria línguanação, suas experiências. Tal situação, não é alheia ao tradutor. Mas, não pode ser superada pelo estabelecimento das línguas em suas diferenças. Não nos opomos, completamente, a essas distinções. Mas, relevamos, em nosso trabalho, a urgência dessas línguas sedimentadas através das fronteiras coloniais e das experiências dos povos nessas geografias, em seu local.

\section{Os poemas e as traduções}

Dito isso, apresentaremos uma breve consideração para, concomitantemente, darmos a ver os poemas traduzidos. Mais além, faremos um breve comentário sobre o arranjo e a composição das traduções dos textos a saber: "Sigue..." de Nicóllas Guillén, cubano; "L'homme qui te ressemble" de René Philombé (1997), camaronês; e, finalmente, “Amanhecer" de Agostinho Neto, angolano. 
Três homens negros, localizados em diferentes partes de uma geografia cuja relação fronteiriça não ocupa o sagrado lugar da escritura legal ou religiosa. Mas, de um complexo de experiências comuns que os tornam reconhecíveis entre si, sendo, por isso, mediadores de suas localidades. Pois, as suas relações com as suas línguas, dos seus respectivos estados nações, vêm de uma imposição colonial, e mesmo sob esse contexto, ainda permeiam o encontro de vozes que interagem, co/agem em ações intuitivas, pois, corporais que fazem ecoar a sonoridade das suas urgências próprias e as urgências dos seus lugares. Mas, não só por essas urgências são reconhecíveis. E mesmo que asilados em suas línguas-nações, ainda, permanecem abertos e sonantes ao projeto de não se entregar à sorte de um exílio sem correspondência. Ao consentir numa renúncia que é o abrir-se em relação.

Esse é um vir-a-ser negro do pensamento tradutório.

Por isso, são, além de poemas, cartas abertas vindas de lugares distantes, mas que atravessam (transversam) lugares para o encontro onde geografia alguma é referência definitiva. Fazendo do corpo-poema o toque na terra mais presente, o outro de si que é a diversidade em pertencer a essa raça, a negra, acima de qualquer território instituído: por isso, Siga... com Nicólas Guillén.

Pois, o locus temporal do nascimento (e do seu devir) não corresponde ao tempo coletivo sob a insígnia do nacional, do pátrio. Qual reluta em seguir a direção de um tempo Histórico. Por tudo

Siga...

Anda, caminhante, siga; caminhe e não se contenha, continue.

Quando passar por sua casa não o diga que me viu: Anda, caminhante, continue.

Siga e não se contenha, continue:

não a olhe se te chama, continue;

lembre-se que ela é má, e continue.

\section{Nicólas Guillén} isso, o início (origem) deve ser uma reivindicação suprassolitária, como o fim é um lugar alheio ao tempo onde acordamos pertencer. Aí, nesse pertencer, a verdade não é solidão. Ela não nomeia, solitariamente, qualquer gesto simbólico comum. E segue. 
Disso, acompanhamos com Guillén em direção a Agostinho Neto com o qual assistimos ao amanhecer de sua África (que perseguimos ou expectamos de muitas formas), num[a]manhã como fresta que se abre ao homem que possamos ser e qual me traduz René Philombé.

No entanto, sempre suspeitando dos regimes representacionais (HALL, 2007) forjados na cor com a qual nos fixaram o ser, o dos pertencentes à raça negra, em qualquer tempo, pelas civilizações europeias em seus empreendimentos coloniais, universalizadores, portanto.

\section{Amanhecer \\ Há um sussurro morno \\ sobre a terra; \\ digladiam-se \\ luz e trevas \\ pela posse do Universo; sente-se a existência \\ a penetrar-nos nas veias vinda lá de fora \\ através da janela; \\ cresce a alegria na alma}

a Vida murmura-nos doces fantasias.

Tangem sinos na madrugada vai nascer o sol.

\section{Agostinho Neto}

Mesmo assim, como tecido e textura, vestimos essa negra letra, que não é regra, com o afro pelo qual grafo aquela inominável matéria “que é tanto ancestral quanto descendente" sob o nome de tradução, onde o poema como potência é também, "a protoforma da progenitura por excelência” (SODRÉ, 2017).

Por isso, insisto que

[..] em qualquer acepção - inclusive naquela atinente à verbalização ou à fala - a comunicação implicada referese primordialmente a um comportamento ou à ação simbólica de vincular ou pôr em comum partes diferentes no interior de um sistema (SODRÉ, 2017, p. 190).

Assim, através dos poemas, como chão que traduz, tento escutar a fala; não mais como a representação de alguma ideia, porém, como a assunção permanente de um grito "comum" emergindo no interior de "um sistema" que faz calar e silencia. Mas, quando oportuno, é afrontado em qualquer front possível, em acontecimentos insuspeitados, - vindos de muitos lugares do mundo (GLISSANT, 2005) - mas, que sempre suspeitamos e conhecemos, mais intimamente, como racismo, em muitos nomes e traduções. 
Em travessia, compartilho um lugar-comum que é a poesia onde "O homem que te parece" bate à porta para oferecer-se a si mesmo opaco, ainda que sonoro, no simples gesto de um toc-toc (mesmo que surdo) tal como um pássaro exigindo morada numa árvore/Tempo. Pois, "Quem vai evitar que os ventos/ Batam portas mal fechadas/ Revirem terras mal socadas/ E espalhem nossos lamentos”. E ainda, “[...] quem paga o pesar/ Do tempo que se gastou/ De las vidas que costó/ De las que puede costar” (BUARQE; NASCIMENTO; MILANÉS, 1978). Escutemos, ainda,

\section{O homem que te parece}

Eu bati em tua porta

Eu toquei teu coração

por uma boa cama

por um fogo bom

porque me repelir?

Abra-me, meu irmão!

Porque me perguntar

se sou de Africa

se sou de América

se sou de Europa?

Abre-me, meu irmão...!
Porque me perguntar

a largura do meu nariz. a espessura da minha boca a cor da minha pele e o nome dos meus deuses? Abra-me, теи irmão...! eu não sou um negro

eu não sou um vermelho

eu não sou um amarelo

eu não sou um branco

mas, eu não sou mais que um ho-

mem,

Abre-me, meu irmão...!

Abre-me a tua porta

Abra-me o teu coração

Pois, en sou um homem

o homem de todos os tempos

o homem de todos os céus

o homem que a ti parece!...

René Philombé 


\section{Considerações}

É mesmo possível ver as auroras do Congo que invadem as janelas ao amanhecer em Luanda, quando um negro do Harlem conta histórias dos grandes rios profundos da África (HUGHES, 1994). Ele os conhece sem nunca ter estado lá. E, mesmo em Havana, também nossa morada, precisamos seguir mais adiante. E se chamam pelo meu nome comum, não respondo. Não reconheço do que me nomeiam. Sou um negro, mas como sei disso? E, apesar disso, toda-palavra me serve. Mesmo as que, por má fé, se aglutinam ao meu redor. Sobre mim. Em torno de nós.

"Abra-me tua porta, meu irmão!" E, por uma abertura, o Outro se deixa entrar. Por uma fissura, o possível amanhece e o diverso, toda linguagem em tradução, renomeia um nome numa afirmação. E o que foi negado parece mais próximo. E o mais distante, como se memória, jamais se ausentara da pele do corpo. Pois,

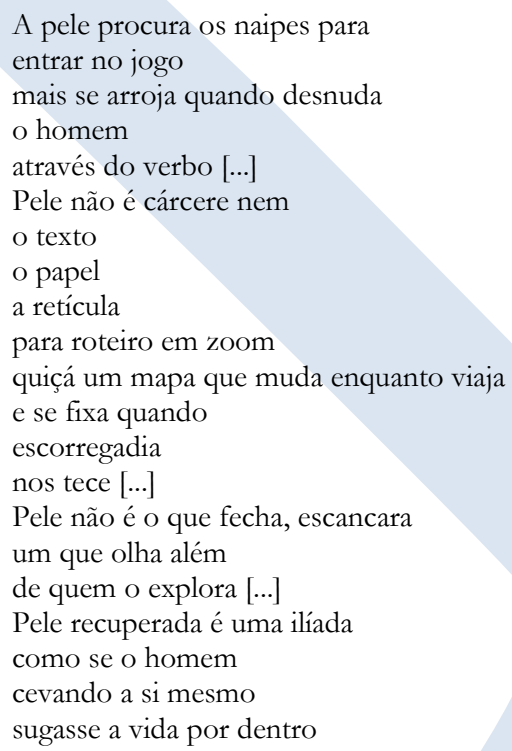

E, assim, sem grandes explicações sobre os mecanismos tradutórios pois, não são, simplesmente, manuseáveis como regras. Ou mesmo, critérios explícitos para a seleção do 
corpus. Como uma escolha aleatória. Em um mecanismo randômico cuja matemática imprevisível responde a todos as perguntas jamais feitas. Por isso, não iremos exagerar, fazer uma exegese para a "compreensão" dos textos. Seja em língua fonte ou em língua alvo.

A minha vontade, nesse trabalho, como já fora mencionada, é dar notícias das terras estrangeiras povoadas por mim, pelos meus. Aqui, o tradutor nada mais é que um correspondente. É um leve-traz de mensagens destinadas a diversos lugares, mas que, no entanto, sabe que existem palavras que só podem ser traduzidas com o próprio corpo. E pelo corpo próprio serem lidas.

Assim, não há (entre-nós) mais que tradutores, mais que mediadores. Como expressei no início deste ensaio, e me repito em diferença, são corpos [como] "organizações" simbólicas - episteme - de mediação das diferenças e identidades (“culturais”) articuladas de modo compósito, em outras palavras, por meios “mais possíveis”. Em que,

[...] o símbolo [o simbólico] em sua originariedade não significa nada, isto é, não remete a nada além dele mesmo, porque sua função primeira é a de organizar elementos, pondo-os em interação tanto opositiva quanto combinatória. É, assim, uma abstração que, uma vez constituída em textura própria, funciona como mediação ou equivalência para objetos diversos e esparsos num mesmo nível de realização de trocas ou numa mesma forma assumida pelo valor. A mediação é uma representação ou, no limite, um texto, que pode concretizar-se em palavras ou em imagens. Vale a lição de Ricoeur quando este afirma que "antes de se tornar texto, a mediação simbólica tem uma textura". Em outras palavras, antes de converter-se em algo que signifique, a mediação é só o resultado do ato de vincular partes ou tecer, portanto, a superfície ou a "pele" de uma forma, algo apenas visualizável ou tocável (SODRÉ, 2017, p. 191 grifo meu)

Num arremedo, como um frágil conbecimento no dizer glissaniano, aponto para o grifo da citação acima, ao que Stuart Hall (1997) vai dizer, sobre as imagens e, coextensivamente, às palavras, é que por essas, também fixamos aquelas. Porque,

Elas acumulam ou eliminam seus significados face às outras por meio de uma variedade de textos e mídias. Cada imagem tem seu 
próprio significado específico. No entanto, em um sentido mais amplo sobre como a "diferença" e a "alteridade" são representadas em uma determinada cultura, num momento qualquer, podemos ver práticas e figuras representacionais semelhantes sendo repetidas, com variações, de um texto ou local de representação para outro. Essa acumulação de significados em diferentes textos, em que uma imagem se refere a outra ou tem seu significado alterado por ser "lida" no contexto de outras imagens, chama-se intertextualidade (HALL, 2007, p. 150).

Ao tempo que: Nada do que digo lhe repito do mesmo jeito / Nada do que digo, lhe repito do mesmo jeito / Como a sombra que o sol te faz caminhando contra luz / Nas costas do seu corpo existe o teu segredo / Navegá-lo é o que insisto.

Seguiremos, ainda... pois, é o corpo quem nos traduz... a nós mesmos por outros, quais reconheço como se a mim mesmo em suas máximas diferenças.

\section{REFERÊNCIAS}

ARISTÓTELES. Organon. Tradução de Edson Bini. São Paulo: Edipro, 2010.

BENJAMIN, W. A tarefa do tradutor. In: BRANCO, L. C. A tarefa do tradutor, de Walter Benjamin: quatro traduções para o português. Tradução de Karlheinz Barck e outros. Belo Horizonte: Fale/UFMG, 2008. p. 51-66.

BHABHA, H. K. O local da cultura. Tradução de Myriam Ávila e Eliana Lourenço de Lima Reis e Gláucia Renate Gonçalves. Belo Horizonte: UFMG, 1998.

CARRASCOSA, D. Traduzindo no Atlântico Negro. Salvador: Ogun's Toques Negros, 2017.

DELEUZE, G. Conversações. Tradução de Peter Pál Pelbart. Rio de Janeiro: 34, 2013.

DELEUZE, G.; GUATARRI, F. Lógica do Sentido. In: Platão e o Simulacro. Tradução de Luiz Roberto Salinas. São Paulo: Perspectiva, 1974. p. 259-271.

DERRIDA, J. A Estrutura, o Signo e o Jogo no Discurso das Ciências Humanas. In: DERRIDA, J. A Escritura e a Diferença. São Paulo: Perspectiva, 1971. p. 229-249.

DERRIDA, J. Gramatologia. Tradução de Miriam Chnaiderman e Renato Janine Ribeiro. São Paulo: Perspectiva, 2006.

DERRIDA, J. Gramatologia. Tradução de Mirian Chnaiderman e Renato Ribeiro. São Paulo: Perspectiva, 2006. 
DIAGNE, S. B. A negritude como movimento e como devir. Ensaios Filosóficos, v. Volume XV, p. 25-35, Julho 2017. Tradução por Cleber Daniel Lambert da Silva.

FANON, F. Peau noire masques blancs. FFrancis jeanson. ed. Paris: Éditions du Seuil, 1971.

GLISSANT, E. Poétique de la relation. Paris: Gallimard, 1990.

GLISSANT, É. Poétique de la relation. Tradução de 1990. Paris: Gallimard, 1990.

GLISSANT, É. Traité du Tout-Monde - Poétique IV. Montréal: Gallimard, 1997.

GLISSANT, É. Introdução à uma poética da diversidade. Tradução de 2005. Juiz de Fora: UFJF, 2005.

GLISSANT, É. L'imaginaire des langues. Entretiens avec Lise Gauvin (1991-2009). nrf. ed. Paris: Gallimard, 2010.

GUILLÉN, N. Motivos de son. In: Sigue. Tradução de Edson César. Havana: Pólvoras de alerta, 2012. p. 43.

HALL, S. Da Diáspora: identidades e mediações culturais. Tradução de Adelaine La Guardia Resende. Belo Horizonte: UFMG, 2003.

HALL, S. A identidade cultural na pós-modernidade. Rio de Janeiro: DP\&A, 2004.

HALL, S. O espétaculo do outro. In: Cultura e Representação. Rio de janeiro: Apiocuri e PUC Rio, 2016.

HEIDEGGER, M. Ser e Tempo. Petrópolis: Vozes, 2003.

HEIDEGGER, M. A origem da obra de arte. Tradução de Idalina Azevedo e Manuel António de Castro. São Paulo: 70, 2010.

HEIDEGGER, M. Ensaios e Conferências. Tradução de Ernildo Stein. Pétropolis: Vozes, 2012.

HUGHES, L. The Negro Speaks of Rivers" from Collected Poems. In: The Negro speaks of rivers. [S.1.]: Harold Ober Associates Incorporated, 1994.

MARTINS, L. A fina lâmina da palavra. O eixo e a roda: v. 15, 2007, Belo Horizonte, v. 15, p. $55-84,2017$.

MARTINS, L. M. Afrografia da Memória. O Reinado do Rosário no Jatobá. São Paulo: Perspectiva, 1997.

MBEMBE, A. Crítica da Rąão Negra. Tradução de Sebastião Nascimento. São Paulo: n-1 edições, 2018.

NIETZSCHE, F. A gaia ciência. Tradução de Paulo César de Souza. São Paulo: Companhia das Letras, 2001. 
PAZ, O. O arco e a lira. Rio de Janeiro: Nova Fronteira, 1982.

PEREIRA, E. D. A. Caderno de Retorno. 2a . ed. Salvador: Ogum’s Toques Negros, 2017.

PHILOMBÉ, R. Petites gouttes de chant pour créer l'hommePetites gouttes de chant pour créer l'homme. [S.1.]: Éditions Semences Africaines, 1977.

PLATÃO. A República. Tradução de J. Guinsburg. J. Guinsburg. ed. São Paulo:

Perspectivas, 2014.

SODRÉ, M. Claros e Escuros. Petrópolis: Vozes, 1999.

SODRÉ, M. Pensar Nagô. Petrópolis: Vozes, 2017.

TYMOCZKO, M. Post-colonial writing and literary. In: BASSNETT, S.; TRIVEDI, H. Post-colonial Translation, Theory and practice. London: Routledge, 2002. p. 19-4-.

TYMOCZKO, M. Ideologia e a posição do tradutor. Tradução de Ana Carla Teles.

Florianópolis: PGET/UFSC, 2013. p. 115-148

Recebido em: 05/08/2018.

Aprovado em: 23/12/2018. 